\title{
Als het ehebedde door de doot gebroocken wort : een beknopte beschouwing over enige facetten van devolutierecht aan de hand van enkele oud- 'Limburgse' rechtsoptekeningen
}

Citation for published version (APA):

Gehlen, A. F. (1989). Als het ehebedde door de doot gebroocken wort : een beknopte beschouwing over enige facetten van devolutierecht aan de hand van enkele oud-'Limburgse' rechtsoptekeningen. LGOG. https://doi.org/10.26481/spe.19890601tg

Document status and date:

Published: 01/06/1989

DOI:

$10.26481 /$ spe.19890601tg

Document Version:

Publisher's PDF, also known as Version of record

Please check the document version of this publication:

- A submitted manuscript is the version of the article upon submission and before peer-review. There can be important differences between the submitted version and the official published version of record. People interested in the research are advised to contact the author for the final version of the publication, or visit the DOI to the publisher's website.

- The final author version and the galley proof are versions of the publication after peer review.

- The final published version features the final layout of the paper including the volume, issue and page numbers.

Link to publication

\footnotetext{
General rights rights.

- You may freely distribute the URL identifying the publication in the public portal. please follow below link for the End User Agreement:

www.umlib.nl/taverne-license

Take down policy

If you believe that this document breaches copyright please contact us at:

repository@maastrichtuniversity.nl

providing details and we will investigate your claim.
}

Copyright and moral rights for the publications made accessible in the public portal are retained by the authors and/or other copyright owners and it is a condition of accessing publications that users recognise and abide by the legal requirements associated with these

- Users may download and print one copy of any publication from the public portal for the purpose of private study or research.

- You may not further distribute the material or use it for any profit-making activity or commercial gain

If the publication is distributed under the terms of Article 25fa of the Dutch Copyright Act, indicated by the "Taverne" license above, 


\section{ALS HET EHEBEDDE \\ DOOR \\ DE DOOT GEBROOCKEN WORT}

Een beknopte beschouwing over enige facetten van devolutierecht aan de hand van enkele oud-'Limburgse' rechtsoptekeningen

REDE

uitgesproken bij de aanvaarding van het ambt van bijzonder hoogleraar in de rechtsgeschiedenis van de Limburgse Territoria aan de Rijksuniversiteit Limburg te Maastricht op donderdag 1 juni 1989

door

Mr. A.FL. GEHLEN 
'La variéte et la souplesse des solutions coulumières d'antan peuvent fournir au juriste actuel un point de comparaison utile, et pourquoi pas? - une source d'inspiration pour aménager le droit d"aujourd"hui."

* Ph. Godding. Lignage et menage. Les droits du comioin survivam dans l'ancien droit bet ge. In: Bibliotheque de la faculte de droit de
I"umiversite catholique de Louvain, XI, Famitle, Droit et changement social dans les societés. contemporaines. Bruxelles-Paris, 1978, p. 277. 
Dames en Heren hoogleraren, hoofddocenten, docenten en medewerkers werbonden aan deze universitaire gemeenschap,

\section{Dames en Heren studenten,}

en voorts Gij allen, die deze plechtigheid met Uw mij verheugende aanwezigheid vereert, waaronder in het bijzonder $U$, mevrow en heren leden wan het Bestuur van het Limburgs Geschied-en Oudheidkundig Genoorschap,

\section{Zeer gewaardeerde roehoorders!}

Door rechtshistorici, die een juridische last van eeuwen mogen dragen onder de verplichting deze - salva rerum substantia - in een eigentijdse verpakking door te geven aan rechtsbeoefenaren, wordt telkens weer erop gewezen hoezeer het voor aanstaande juristen van belang is, dat zij reeds tijdens de eerste jaren van hun juridische vorming kennis maken met en zich verdiepen in de geschiedenis van het recht. Veelvuldig is dan ook betoogd, dat beoefening van de rechtsgeschiedenis een bij uitstek geschikt middel is om juristen in statu nascendi met de rechtstaal vertrouwd te maken, om hun juridisch denken te scherpen, om hen in te leiden in zaken van juridische systematiek en casuïstiek en bovenal ook om hen het nodige besef bij te brengen dat er dikwijls een nauwe samenhang bestaat tussen rechtsinstituten en rechtsnormen die wij vandaag de dag kennen en daarmee vergelijkbare rechtsfenomenen, die ook vele van onze voorouders bekend waren, of clat er - in andere gevallen - van een zodanige correlatie, om welke reden dan ook, juist geen sprake is. ${ }^{1}$ Aldus beschouwd, kan de beoefening van de rechtsgeschiedenis derhalve niet alleen leiden tot het verwerven van bepaalde vaardigheden en inzichten, die voor een jurist nuttig of wenselijk zijn, maar vooral ook tot verruiming van zijn kijk op zaken van recht. En in de rechtspraktijk van vandaag en zeker in die van morgen, die immers naar het zich laat aanzien nog complexer zal zijn dan de tegenwoordige, is een wijdse blik op het uitgestrekte terrein van het recht van eminent belang.

In deze oratie moge $U$ dan ook enkele rechtsregels en rechtsopvattingen uit het verleden worden voorgelegd, die mede gelet op de aard van onze leeropdracht door ons worden opgediept uit de zeer rijke rechtshistorie van een aantal territoria die, na de vorming van het Koninkrijk der Nederlanden, sedert 1839 deel zijn gaan uitmaken van de Nederlandse provincie Limburg. Aldaar zijn zij gedurende de late middeleeuwen en ook nadien tot aan de Franse Omwenteling toe en zelfs nog enige decennia daarna van groot gewicht geweest, alleen al vanwege het feit dat vroeg of laat tijdens hun leven vele bewoners van deze Maasstreken ermee in aanraking kwamen. "Vgl. J.Ph. de Monté ver Loren, Hoofalijnen
uir de ontwikkeling der rechterlijke organisarie
in de Noordelijke Nederlanden lo de Bataafse
Onwenteling, ode druk bewerkt door f. Spruit, Deventer 1982, p. 3 en de aldaur in $n$. 5 genoemde literatuwn. 
In de rechtshistorische literatur worden de bedoelde regels en opvatungen onder en gemeenschappelijk noemer gebracht en aangeduid als devolutierech, een complex van rechtsverschijnselen, waardoor werd bepaald hetgeen in vermogensrechtelijk opzicht voor recht gehouden werd in geval een van wee chtelieden kwam te overlijden met achterlating van een of meer uit zijn huwelijk geboren kinderen.

Wij bevinden ons op het terrein van het familievermogensrecht waar kwesties wan huwelijksgoederentecht en erfrecht dikwijls met alkander verstrengeld zijn danwel in elkaars verlengde liggen. Reeds een eerste kennismaking met de literatuur op het stuk wan het devolutienecht leert, dat het instituut door de schrijvers nu aens behandeld is in het kader van het huwelijksgoederenrecht dan weer in dat van het erfrecht. Mejjers in zijn baanbrekende studie ower het Ligurisch erfrecht in de Nederlanden bracht het devolutierecht ter sprake in zijn rechtshistorische beschowwingen over het huwelijkgoederenrecht. Door hem werd het devolutierecht eerst en vooral opgevat als een gevolg van een eigenaardige gemeenschap van goederen, die door kindsgeboorte tussen ouders en kinderen ontstond. Na het overlijden van een der ouders $k$ wamen de goederen van deze gezamendehandse of gebonden gemeenschap weliswaar aan de langstlevende, doch om over de goederen te kunner beschikken behoefde hij de medewerking wan de uit het huwelijk geboren kinderen, aldus deze auteur. ${ }^{2}$ Ook in de Duitse rechtshistorische literatuur, waar het devolutierecht wordt aangeduid als 'Verfangenschaftsrecht', geschiedt de bespreking wan de desbetreffende regels doorgaans bij de behandeling van het "eheliches. Güterrecht." In het in 1987 onder de titel "Le droit privé dans les Pays-Bas méridionaux du $12 \mathrm{e}$ au $18 \mathrm{e}$ siècle' verschenen magistrale handboek van de Leuvense hoogleraar Godding daarentegen vindt "le droit de dévolution" een uitvoerige bespreking in het kader van het erfrecht bij versterf." Voor deze behandeling in het geheel van het erfrecht valt zeker veel te zeggen, immers daar waar bij het streven naar schriftelijke optekening van het gewoonterecht ook de regels op het stuk van het devolutierecht werden opgetekend, vonden deze merendeels hun plaats temidden van de bepalingen aangaande het erfrecht bij verster $\mathrm{C}$.

Central in het geheel der devolutieregels stond het beginsel dat na het overlijden van een der echtgenoten de langstlevende humner enerzijds gerechtigd was de onroerende goederen, die tijdens het huwelijk hetzij tot de respectieve privé-vermogens der echtgenoten hetzij tot hun gemeenschappelijk vermogen behoorden, san zich te houden, daarover het beheer te voeren en de vruchten

2. M. Meyers, Het Ligurisch eifrectin in de Nederlandew, DI. 1. Met Westowabantsche Erfrechi, Hawerm 1929, p. 33-34; zie ook A.S. de Blacoust, Kori begrip wan het Oud Vaderlands Burgenligk Rechi, 7 de drak bewerkt door H.F.W.D. Fischer, Gromingen $1969,0,76$

- Zie bijv, A. Hewser, Insivuronem des Deurschen Primatrectios, Bnd. 11, Leipzig $1886, p$.

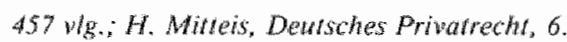
Aufage nubearb. 1. H. Lieberich, Manchen 1972, 11.1.2, 18.1.2, 18.11.2.; R. Shhröder E. Fh. v. Kunsberg, Letrowch der dewschen Rechrsgeschichre, 7. Alufloge, Berhn-Leipzig 1932, p. $810 \mathrm{w} / \mathrm{g}$

* Ph. Godding, Le dront privé dans les PaysBas meridionat du 12 an $18 \mathrm{e}$ siede, Braxel les 1987. mrs. 639-656. 
daarvan te trekken, terwijl hem anderzijds het recht ontzegd werd over die goederen te beschikken, opdat deze na zijn overlijden 'in iure pleno' (in volle recht) zouden gaan toebehoren aan de wit het huwelijk geboren kinderen. Hertrouwde de langstlevende en werden er uit dit volgende huwelijk eveneens kinderen geboren dan konden bij zijn overlijden deze laatsten rechtens geen aanspraak maken op die goederen, omdat die bij ontbinding wan het eerdere huwelijk waren gedevolveerd - zoals dat heette - op de kinderen uit het vroegere echtelijk bed.

Deze essentialia van het devolutierecht komen woor in vele laatmiddeleeuwse en latere rechtsbronnen uit de Westfaalse-, Frankische-, Thüringse- en Zuidduitse landen van het Heilige Roomse Rijk; woorts in noordoostelijke en noordelijke delen van de Franse "pays du droit coutumier" - met name in Elzas-Lotharingen en Artesië - en voor wat de Lage Landen betreft in Henegouwen, in het oostelijk deel van Brabant, in Luxemburg, Namen en Luik en ook in territoria, die we nu maar gemakshalve als oud-'Limburgse' zullen aanduiden.

Wij bepalen ons in het navolgende tot deze laatste en gaan na, welke regels van devolutierecht in deze 'Limburgse' landen oudtijds in zwang waren en welke hun juridische betekenis geweest is. Beknoptheid in ons betoog is geboden, reden waarom volstaan moet worden met de aanduiding van slechts enkele hoofdlijmen, die zichtbaar worden bij een eerste beschouwing van een aantal opgetekende regels van devolutierecht zoals die worden aangetroffen in het oud-Maastrichtse recht en in enkele kenbronnen uit het Valkenburgse land van Overmaze en uit het zogeheten Overkwartier van Roermond.

Allereerst iets over de wijze waarop aan de vermogensrechtelijke rechtspositie van de langstlevende ouder en die van de uit het huwelijk geboren kinderen in de verschillende rechtsoptekeningen aldaar in hoofdtrekken vorm was gegeven.

Voor het tweeherige Maastricht werd reeds in zgn. 'Alde Caerte' van $\mathbb{1 2 8 3}$ bepaald, dat in geval van overlijden van een der beide echtelieden met achterlating van kinderen de langstlevende ouder alle onroerende goederen mocht 'behouden'. Daarbij werd geen onderscheid gemaakt tussen patrimonialeen/of stokgoederen, die vóor of tijdens het huwelijk door de echtgenoten van hun ouders of grootouders waren geërfd, enerzijds en zgn. 'acquesten', die tijdens het huwelijk door hen gezamenlijk waren verkregen, anderzijds. Na het overlijden van de langstlewende 'keerden' al deze onroerende goederen op hun

${ }^{5} \mathrm{Vgl}$ voor de genoemde territoria in thet Heillge Roovrse Rijk R. Schröder-E. v. Künssberg, Lehrbuct, p. 810; voor Frankrijk P. Viallet, Histoire au droit civil francas, $3 e$ ed. Paris 1905, p. 901-902; voor de Lage Landen Ph. Godding. Le droir prive, nr. 643. Vgl. voor Leuven en 's-Hertogenbosch R. Byl, Contribution a l"étude de la succession ab intestat el du regime matrimonial en droil contumisr de Lowvain ef de Bois-le-Duc, in: Bulletin de la Commissian Royale des anciennes lois et ordomances de Belgique. Tone $X X V$. 1971.1972, Bruxelles 1973; zie voor JullichBerg K-H. Horbach. Das Privatrecht der Re formation won Jialich-Berg aus dem Jahr 1555 (ctiss. Unversitat Kotm 1981), p. 68-72. 
gemeenschappehjke kinderen, 20 bepaalde de 'Alde Caerte". In nagenoeg gelijke bewoordingen werd dit zelfde devolutiebeginsel bijna vien eeuwen later opnicuw neergelegd in de Maastrichtse recessen anno $1665^{7}$ In beide genoemde rechisoptekeningen was yoorls bepaald, dat alle roerende goederen zouden toebehoren an de langstevende war dan tegenover stond dat alle schulden voor diens takening kwamen."

De in 1570 en weerom in 1612 opgetekende costumen uit het Valkenburgse land van Overmaze bevatten op het stuk van het devolutierecht een antal regelingen waaruit eveneers blikt, dat onroerende goederen, die de echtgenoten hetzij in prive hetzij gemeenschappelijk toebehoorden, bij het overlijden wan de eerste hunner op hun gezamenlijke kinderen devolveerden en dat het gebruik dier goederen de langstlevende ouder gereserveerd was."

In de in 1619 opgetekende "Gelderse Land-en Stadrechten in het Overkwartier van Roermond" was bepaald, dat in geval "het ehebedde door de doot gebroocken" werd alle roerende goederen de langstlevende volgden onder de last dat hij alle schulden voor zijn rekening zou nemen. Onroerende goederen, zowel patrimoniale als die "gewonnen ende geworven oft verovert" waren, vielen terstond in eigendom toe aan de wit het huwelijk geboren kinderen, in dier voege evenwel, dat de langstlevende ouder de 'tochte' (gebruk) dier goederen zou genieten. ${ }^{10}$

Een eerste belangrijke kwestie, die bij de bestudering van deze rechtsopteke. ningen nadere beschouwing verdient, betreft het juridische karakter van dit devolutiefenomeen. Hoe zijn de rechtspositie van de langstlevende ouder en die van de uit het huwelijk geboren kinderen met betrekking tot de goederen die op cleze kinderen rechtens devolveerden, juridisch te qualificeren?

De literatuur in dezen confronteert ons met twee onderling verschillende opvattingen, die door de eeuwen heen beide hun verdedigers vonden.

In het bellangwekkende in 1666 verschenen 'Tractatus de jure devolutionis' van Petrus Stockmans - destijds raadsheer in de Brusselse Soevereine Raad van Brabant en hoogleraar te Leuven - werd uitvoerig betoogd, dat niettegenstaande het feit dat in diverse costumen de langstlevende ouder met betrek-

\footnotetext{
" De desberrefiende porsuge in de "Alde Corw

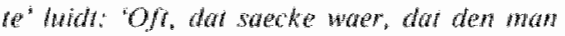

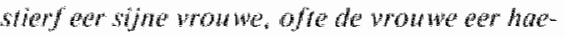

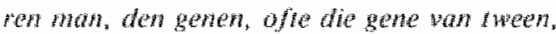

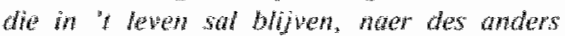
doodt, sal behowder, alle siju lewen, horrer beyder erve. Ende sal hebbat, in deringer sid-

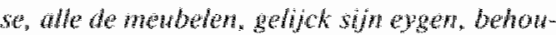
detick hof resramenf wh den dooden. endo de sichulden. Muer naer die doadr wan man, ofik wrow we. die 'i leste sal lewen als hier boven is seseyd. alle haer erve, woorgenoent, is schutdigh te heenen op humbe gameyne kindenen, soo syer hebben te goeder gewommen. met hat sulfs lifven." (uit: Recueil der Recessen, wegens beyde de genatige Heeren ande Princen, al-
}

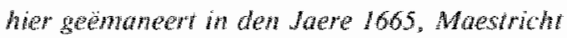
1719. p. 201). Zie wakak de onderscheiding "parimoniale goedengn". "stokgoedenen" en "acquesten", E. Defacaz, Anchen Dron Belgique, T.II, Brukelles 1373, p. 49.50; Ph. Cod ding. Le droit prive, $n \pi, 202$.

"Recueil der Recossen, Cap. XLMI, I en 2.

$\mathrm{Wg}$. noot 6 en Recuell der Recessen. Cap. $X l \| l, l$.

- K.d. Th. Janssen de Limpers, Rechtsbromen wan thet herlogdom Limburg en de Landen wan Overmaze (hierna: Rbr. L. en LVO.), Bussum 1977, p. 483/6) en p. 490-491(6).

1. Gelresche Landt ende Stad-Rechten im" Over Quarier van Ruremonde Arahem $1679^{\circ}$ (hierna: G.L.S.R.) fol, 24 (1I en 12). 
king tot de op de kinderen gedevolveerde goederen dikwijls als "erftochter" werd betiteld, diens positie toch niet op een lijn gesteld kon worden met die van een 'usufructuarius' (vruchtgebruiker), doch dat deze zogeheten 'erftochter veelleer was aan te merken als een "proprietaris", die slechts inzoverre in de uitoefening van zijn volle rechten beperkt was, dat hij niet vrijelijk over de boedelgoederen kon beschikken ten detrimente van de kinderen, die uit het huwelijk geboren waren. Het recht van de langstlevende werd opgevat alls 'proprietas frenata', als 'propriété bridée', als een aan de lijn gelegd of gebreideld eigendomsrecht. De kinderen kregen als gevolg van het overlijden van de eerstgestorven ouder niet meer dan een verwachting, die eerst in vervulling zou gaan wanneer de langstlevende ouder kwam te overlijden. " Deze zelfde opvattingen aangaande het karakter van de devolutie treffen we aan bij $18 \mathrm{de}$ eeuwse Zuidnederlandse auteurs als Jean Alphonse de Coloma en Georges de Ghewiet, bij 19de-eeuwse schrijvers als Merlin en Laurillard en ook in het recente, reeds hiervoor genoemde handboek van Godding. Het onderzoeksterrein van deze auteurs betrof vooral territoria in de Zuidelijke Nederlanden. ${ }^{12}$

In het Tijdschrift voor Rechtsgeschiedenis van 1955 werd daarentegen door Imbert betoogd, dat in de Elzas, in en rondom Metz alsook te Namen, in ieder geval sedert het einde van de 17 de eeuw, de langstlevende ouder met betrekking tot de onroerende boedelgoederen als een vruchtgebruiker werd gezien en de uit het huwelijk geboren kinderen als blote eigenaren, die ook gerechtigd waren de bij het overlijden van de eerstgestorven ouder op hen gedevolveerde blote eigendom te vervreemden. ${ }^{13}$ Ter ondersteuning van deze opvatting over het karakter van de devolutie in de door hem doorzochte territoria verwees Imbert behalve naar $18 \mathrm{de}$ - en vroeg-19de-eeuwse auteurs naar rechterlijke uitspraken en naar de inhoud van costumiere bepalingen, zoals die aldaar in de 18 de eeuw werden opgetekend. ${ }^{14}$

Het bestaan van deze beide onderling verschillende theorieën over de aard van het devolutierecht behoeft intussen geen verwondering te wekken. Bekend is immers dat al naar gelang tijd en plaats in de diverse gewoonterechtelijke rechtsoptekeningen de nadere uitwerking van het devolutiebeginsel niet alleen in details, maar ook op juridisch meer essentiële punten verschillend is geweest. " En verschillen spelen nu eenmaal een belangrijke rol bij de qualificatie van rechtsverschijnselen.

Voor ons is hier aan de orde de vraag naar aard en inhoud van het devolutierecht in de diverse oud-'Limburgse' territoria.

Voor wat Maastricht betreft, is in dezen op basis van de reeds genoemde

1 P. Stockmans, Tractatus de jure devolunio. mis, Brussel 166.72. Cap. $I, 7$.

12 J.A. de Coloma, Arrêts du Grand Conseil de Malines, Malines 1781, $1 ., p .206 ; G$, de Ghewiet, Institutions du Droit Belgique, T.I., p. 345, P. Merlin, Répertoire umiversel et ratsomé de Jurispradence, T.IV, Paris 1827, p. 577.579; I.J.M. Laurillard, Het devolutie-regt in het herrogdom Brabani, Leyden 1855, p. 6;
Ph. Goddhy Le droil prive, nr, 639.

13 J. Mnbert. Le dron de devoluhon dans les courames Nawnoratse. Messine er Alsaciennes, in. Tudschrift yoor Rechseguthedenis 23 (1955), 224-226.

14 I. Inber, te droir de devolution, $p$. $226-228$.

15 Vgl. Ph. Godding, Le droil prive. rir. 64. 
'Alde Caerte' van 1283 en van de Recessen van 1665 in de vorige eeuw door Crahay betoogd, dat aldaar het recht van de uit het huwelijk geboren kinderen ten aanzien van de op hen gedevolveerde goederen gezien werd als hetgeen wij thans blote eigendom ("nue propriété") noemen en het recht van de langstlevende ouder als vruchigebruik ("un simple droit d'usufruit"). Dit impliceerde, aldus deze auteur, dat de blote eigendom der goederen, die op de uit het huwelijk geboren kinderen devolweerden 'etait transmissible à leurs héritiers', waarmee de schrijver - als wij het tenminste wel zien - bedloelde te zeggen, dat bij overlijden der kinderen de blote eigendom overging op hun descendenten, zo die er tenminste waren. ${ }^{16}$ Aangaande de vraag of een kind de blote eigendom van de op hem gedevolveerde goederen ook tijdens zijn leven kon verkopen, bepaalden de Recessen van 1665, dat een dergelijk koopcontract alleen dan effect sorteerde, wanneer de langstlevende ouder-vruchtgebruiker kwam te overlijden vóór het kind dat de blote eigendom had verkocht. ${ }^{17}$ En wat was er rechtens ingeval de bloot eigenaar enig op hem gedevolveerd goed had verkocht en hij vervolgens vóór de wruchtgebruiker kwam te overlijden? Crahay zal aangenomen hebben, naar ik meen, dat dan de blote eigendom overging op de erfgenamen van de overledene en dat de koper tot de volle eigendom kwam, wanneer daarna ook de vruchtgebruiker kwam te overlijden.

Nieuwe ontdekkingen leiden soms tot bijstelling van vroegere visies. Zo'n nieuwe ontdekking vormt mogelijk een tot voor kort onbekend gebleven manuscript, dat in het kader van werkzaamheden aan de inventarisatie der archieven van de Maastrichtse bestuurlijke en gerechtelijke instanties recentelijk tevoorschijn is gekomen bij de stedelijke archiefdienst te Maastricht. Het 24 pagina's tellend handschrift bevat een op 4 januari 1633 door de magistraat van de stad Maastricht aan de Raad van Brabant te 's-Gravenhage toegezonden 'Informatie' aangaande de 'Rechten ende Costuymen', die ter stede van kracht waren tot het ogenblik waarop kort voordien de stad 'pro indiviso parte' bij de Republiek der Verenigde Nederlanden werd geannexeerd. ${ }^{8}$

Waar in deze 'Informatie' het gebruiksrecht van de langstlevende ouder ter sprake komt, worden onderscheiden: het gebruiksrecht voor de langstlevende ten aanzien van de patrimoniale goederen van de overleden echtgenoot enerzijds en het gebruiksrecht van zijn eigen goederen anderzijds. Het eerstgenoemde gebruiksrecht werd aangeduid als 'simple tocht' en het gebruiksrecht ten aanzien van de eigen goederen wan de langstlevende als 'erftochte'. Bij het overlijden van de langstlevende ouder werden deze beide soorten gebruiksrecht op de gezamenlijke kinderen, die uit het huwelijk geboren waren, 'getransmitteent". ${ }^{19}$ In geval van een kinderloos huwelijk volgde de 'proprieteyt' der goederen echter verschillende wegen. De 'proprieteyt' der stok- en patri-

\footnotetext{
4t L. Crahay, Contumes de la wille de MaresIricht, Brutuelles $1876, p . X X V I t$.

"Recwell der Rewessen. Cap. XXXIX, 7 .

" 8 Geneente-archief Matastricht, Rechtertike Archieven, evac, nr. 7438. Gaarne dant ith hier Mr. Thu. wan Rensch, charterneester te Maastrichn, die mij atrendeerde op her mamascript.
}

"In de 'Informatie' lavil de tekst: "Ende soo weere sij caemen te sterven ende wettige kinderen acher te laten erfie die langs leevende inde simple tochte van ale die voors. patrimoniale goeden wan den ersten overleeden ende in wie eerfochle van sijne eljgene goederen ende die roche wordt bij des selffs doode ge. transmituert op hunne beyde kinderen. 
moniale goederen van de overleden echtgenoot vererfde, overeenkomstig de regel 'paterna paternis materna maternis" op diens naaste verwanten, onder bezwaar van 'simple tocht' ten behoeve van de langstlevende echtgenoot, aldus de "Informatie". ${ }^{20}$ De 'proprieteyt" van de eigen goederen van de langstlevende bleef in diens handen, naar ik aanneem, zodat hij over die goederen de volle beschikking kreeg. Met betrekking tot de onroerende goederen, die door de echtgenoten tijdens hun huwelijk anders dan door "successie of legaet" waren verkregen (de 'acquesten'), bepaalden de Recessen van 1665 , dat deze, na kinderloos overlijden van beide echtgenoten, bij helften vererfden op hun wederzijds naaste verwanten. ${ }^{21} \mathrm{Na}$ het overlijden van de eerste der echtgenoten genoot de langstlevende de 'volle proprieteyt' van de ene helft en de 'simple tocht' van de andere helft dier geacquireerde goederen, zo menen wij althans vooralsnog te mogen aannemen.

De Maastrichtse regelingen bij kinderloos overlijden van de eerste der beide echtgenoten stemden overeen met die uit het Overkwartier van Roermond. De 'Land- en Stadsrechten' aldaar bepaalden immers, dat ingeval van een kinderloos huwelijk de langstlevende de volle rechten behield van zijn eigen goederen en eveneens van de helft van de goederen, die staande huwelijk 'gewonnen ende geworven' waren. ${ }^{22}$ Van de erfgoederen van de overleden echtgenoot en van de andere helft der aangeworven goederen genoot de langstlevende de 'naeckte ofte bloote tochte', zo bepaalden de Overkwartierse rechtsoptekeningen. ${ }^{23}$ Met het begrip 'naeckte tocht' moet wel het zelfde soort gebruiksrecht bedoeld zijn als het gebruiksrecht, dat te Maastricht 'simple tocht' werd genoemd, naar mij dunkt. Waren er ten dage van het overlijden van de eerste der echtgenoten kinderen, die uit het huwelijk geboren waren, dan ging in het Roermondse Overkwartier de eigendom van alle onroerende goederen terstond op die kinderen over en de 'tochte' op de langstlevende ouder. De 'tocht' over al die goederen werd hier aangeduid als 'erftochte'. ${ }^{24}$ De Valkenburgse Landen van Overmaze kenden een soortgelijke regeling. De langstlevende ouder werd aldaar 'tochtenaer oft tochtenaersche' genoemd ${ }^{25}$

Bezien wij deze oud-'Limburgse' rechtsoptekeningen tegen de achtergrond van de hiervóór genoemde theorieèn over de aard van het devolutierecht, dan kan, wat de rechtspositie van de langstlewende ouder met betrekking tot de devolutiegoederen betreft, geconcludeerd worden, dat deze langstlevende ouder, zolang er uit het huwelijk geboren kinderen of verdere afstammelingen in leven waren, rechtens niet bevoegd was de op de kinderen of kindskinderen gedevolveerde goederen te vervreemden of te bezwaren. Immers zowel in de opvatting der auteurs die het gebruiksrecht van de langstlevende ouder als 'simple tocht' of als 'erftocht' betitelden, als in de leer der schrijvers, die het gebruiksrecht als 'proprieteyt' zagen, werd aangenomen dat de langstlevende ouder noch tot vervreemding noch tot bezwaring gerechtigd was. Een uitzondering werd wel gemaakt ingeval de langstlevende ouder in financiële nood

$20 \mathrm{Vgl}$. het in noot 18 gencoende manuscript.

"Recueil der Recessen, Cap. XLII, II.

${ }^{22}$ G.L.S.R., fol. 25,15.

${ }^{33}$ G.L.S.R., fol, 25, 16
2.4.L.S.R., fol, $24,12$.

25 Rbr. L. en L en LNO., p. 483(7) an p. $491(7)$. 
verkeerde. In de rechtspraktijk te Maastricht tenminste was her alsdan mogelijk, dat door de langstlevende ouder tot vervreemding of bezwaring wan de op de kinderen gedevolveerde goederen kon worden overgegaan, zulks evenwel niet anders dan met machtiging van een der stedelijke hooggerechten. Teneinde deze praktijk in te dammen resolveerden evenwel op 6 oktober 1740 de commissarissen-deciseurs aldaar, dat een dergelijke machtiging in de toekomst alleen nog maar verleend kon worden krachtens beschikking der beide stadsheren. ${ }^{26}$

De vraag of en inhoeverre na het overlijden van de eerste der beide ouders diens kinderen tot verveemding of bezwaring van de op hen gedevolveerde goederen gerechtigd waren, is in de literatuur verschillend beantwoord. Laurillard, die wan oordeel was dat de kinderen krachtens devolutie vooralsnog niet meer dan een verwaching ten deel viel, huldigde de opvatting dat de kinderen rechtens niet tot vervreending of bezwaring bevoegd waren. ${ }^{27}$ Schrijvers als Crahay en Imbert claarentegen, die de kinderen in dezen als blote eigenaren beschouwden, waren de mening toegedaan, dat zij uit dien hoofde ook tot vervreemding of bezwaring van de blote eigendom gerechtigd waren. ${ }^{28}$ Een verantwoorde stellingname in deze controverse louter aan de hand van de tot dusverre bekende rechtsoptekeningen uit de oud- "Limburgse" territoria is vooralsnog niet mogelijk. Voor wat Maastricht aangaat, doet de hiervóor genoemde 'Informatie' de vraag rijzen of de rechtspositie der uit het huwelijk geboren kinderen niet verschilde al naar gelang het gebruiksrecht van de langstlevende ouder aangemerkt werd als 'simple tocht' danwel als 'erftocht". Eerst na een diepgaand onderzoek in de gerechtelijke procesdossiers en in de protocollen van voluntaire jurisdictie zal op dit punt wellicht iets meer gezegd kunnen worden.

Aan de vraag of op de uit het huwelijk geboren kinderen bij het overlijden van de eerste hunner ouders niet alleen allodiale goederen, die aangeërfd of aangewonnen waren, maar ook leengoederen devolveerden, is in de literatuur nauwelijks aandacht besteed. Voor wat de Brabantse territoria betreft, voorzover die tenminste het devolutierecht kenden, mag worden aangenomen, dat alle leengoederen die van de Brabantse hertog als onmiddellijke heer afhingen, a an het devolutierecht onderworpen waren, zo betoogde althans Laurillard. ${ }^{29}$ Omtrent de andere leengoederen aldaar liet de auteur ons in het ongewisse.

Waar in de Overkwartierse Land-en Stadsrechten van 1619 het devolutierecht ter sprake werd gebracht, werd expliciet bepaald, dat hetgeen in de onderhavige rechtsoptekeningen dienaangaande was neergelegd uitsluitend 'vrije oft allodiale oft schepengoederen', die in het kwartier gelegen waren, betrof. Goederen op andere plaatsen gelegen of die van andere 'aert, nature oft wesen' waren, volgden het regiem van de stad-, land- of hofrechten van de plaat-

2. Recueil der Recessen. Aenhangsel, Resolutie rakende de gedevolveerde goederen niet meen te konnen beswaren als na voorgatande permissie wan beyde de princen in dato den 6 October 1740 (p. 139-14l); zie ook Ph. Gadding, Le aroin prive, $m, 644$.
"7. M.M. Latrillard, Het devolutie-regt, p. 34. is L. Crahay, Condames... Maesiricht, p. XKVIT-XXYIII; I. Imber, Le droit de devolution. D. 226.

2. I.M.M. Laurillard, Het devolutieregt, p. $63 \times 64$. 
sen of hovern, waaronder zij ressorteerden. ${ }^{30}$ Alleen een meer diepgand onderzoek van de desbetreffende rechtsoptekeningen zal duideljk kunnen maken of en inhoeverre aldaar het devolutierecht ool leenroerige goederen raakte.

De Valkenburgse declaraties van 1570 en 1612 bepaalden op het stuk van successie in de rechte lijn, dat wettig geboren kinderen succedeerden in alle goederen hetzij leengoederen oft andere"." Ten aanzien wan leen-, cijns- en latgoederen bevatten deze beide rechtsoptekeningen rechten van primogeni: turr, in die zin dat de oudste zoon - of bij gebreke wan zonen de oudste dochter - in een bevoorrechte positie verkeerde tegenover de overige kinderen. ${ }^{y}$

Naast allodiale of leenroerige huizen, hofsteden, landerijen, beenden, vijvers enz. werden ook onroerende rechten als enfthinsen, erfpachten, erfrenten, tollen en wat dies meer zij in de devolutie betrokken, alsmede goederen die krachtens bestemming voor onroerend werden gehouden. Als zodanig werden in de Overkwartierse rechtsoptekeningen en in de Maastrichtse Recessen onder meer aangemerkt: molens met hun toebehoren, gebruikswoorwerpen voor de eredienst, gereedschap dat diende tot bescherming van kastelen en wersterkte huizen, bepaalde soorten brouwketels en brouwkuipen en verder meer in het algemeen al hetgeen aard-en nagelvast was. ${ }^{3}$ Daarenboven was het devolutierecht ook nog van toepassing op zogeheten "vlieghende" of "rutsende' goederen, die ook wel als 'varende erfitael" werden aangeduid. ${ }^{34} \mathrm{De}$ Valkenburgse costumen noemden als zodanig: alle tin- of koperwerk, dat met de hamer geslagen was, geslagen zilwerwerk, alsmede slaaplakens en beddegoed. 35

Voor het devolutierecht was kenmerkend, zo werd hiervóo betoogd, dat de langstlevende ouder ten aanzien van de goederen, die bij het overlijden van de eerstgestorvene op de kinderen devolveerden, in beginsel beschikkingsonbevoegd was. Wel kon de langstlevende ouder vrijelijk beschikken over de onroerende goederen, die hij na het overlijden van zijn echtgenoot verwierf. In geval hij niet hertrouwde en van zijn recht tot vervreemding van die later verworven goederen geen gebruik maakte, vererfden deze goederen bij zijn overlijden op de wit het huwelijk geboren kinderen. "36

Gecompliceerder werd het echter, wanneer de langstlevende ouder zich in een wolgend huwelijk begaf.

De Valkenburgse costumen bepaalden, dat de uit een eerder huwelijk gebo. ren kinderen, terstond na de totstandkoming wan een nieuw huwelijk wan de langstlevende ouder, gerechtigd waren scheiding en deling te vorderen van de onroerende goederen die op hen gedevolveerd waren. ${ }^{37}$ Rechtens werd aldaar dan onderscheid gemaakt tussen de onroerende goederen die tot het privevermogen van de overleden ouder behoord hadden enerzijds en de zgn. acquesten

10 G.L.S.R., fol. 25,17

is Rar. Len L. wO. p. $482(1)$ en p. $490(1)$.

"Rbr. L. en LwO. p. 482-483(3 en 4) en p. $490,3 \operatorname{en} 4)$

${ }^{3}$ G.L.S.R., fol. 26,I.; Recueit der Recersen, Cap. XXXVIII, $4 \mathrm{wg}$.

\footnotetext{
${ }^{34}$ Zie whake "Wheghende" of "rulsende" goede. ren Ph. Godding, Le alroh prive. nis: 198.

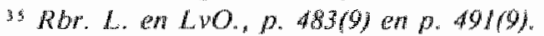

36 Zie Ph. Godding, Le droil prive, nw. 647.

${ }^{37}$ Rbr. L. ew LWO., pl $43(6)$ en p. $490.491(6)$.
} 
of conquesten, die tijdens het huwelik door de ouders gezamenlijk waren verkregen, anderzijs. In het kader wan de scheiding en deling waren de kinderen in de eigen goederen van de overleden ouder alsdan gerechtigd voor de helf en in de gemeenschappelijke goederen woor een vierde deel, zo menen wij de desbetreffende Vakenburgse bepalingen te moeten opvatten. ${ }^{38}$

Diverse vragen dienen zich aan. Welke waren bij scheiding en deling de rechten yan de kinderen ten aanzjen van de eigen goederen van de langstlevende ouder, die toch ook op de kinderen gedevolveerd waren? Werd het effect van de devolutie door de scheiding en deling geheel en al ongedaan gemaakt? Verkreeg de langstlevende ouder na scheiding en deling de volle beschikkingsbevoegdheid over de onroerende goederen die hem werden toebedeeld? In hoeverre gingen deze aan de langstlevende ouder toebedeelde onroerende goederen behoren tot de gemeenschap van goederen, die ontstaan was tengevolge van diens tweede huwelijk? En welke waren de rechten van de kinderen uit het eerste, tweede of wolgend huwelijk ten aanzien van deze onroerende goederen wanneer de hertrouwde ouder kwam te overlijden? De Valkenburgse rechtsoptekeningen gaan aan dit alles woorbij. Slechts nader onderzoek in de Valkenburgse gerechtelijke en notariële archieven kan ons in dezen verder brengen.

Of in het Owerkwartier van Roermond de kinderen gerechtigd waren van de onroerende goederen, die op hen waren gedevolveerd, scheiding en deling te vorderen zodra de langstlevende ouder zich in een volgend huwelijk begaf, daarvan blijkt niet uit de Land-en Stadrechten wan 1619. Well bepaalden deze rechtsoptekeningen uitdrukkelijk, dat in geval van een tweede huwelijk van de langstlevende ouder de onroerende goederen uit het eerste huwelijk, na het overlijden van de langstlevende ouder, vererfden op de kinderen uit het eerste huwelijk. ${ }^{39}$ Kinderen uit een tweede of volgend huwelijk geboren erfden van de desbetreffende ouder niet alleen de onroerende goederen die deze krachtens erfrecht of anderszins had verkregen tijdens het huwelijk waaruit die kinderen geboren waren, doch eveneens de onroerende goederen, die hij verworven had gedurende de periode warin hij zich, voorafgaand aan dat volgend huwelijk, in de 'weduwen stoel' had bevonden. ${ }^{40}$ Onroerend goed dat verkregen was tijdens een latste weduwschap, na twee of meer successieve huweliken waruit kinderen gesproten waren, wererfde op de gezamenlijke kinderen, ongeacht of dic wit het eerste of uit een volgend bed stamden. ${ }^{4}$

Hoewel in de Maastrichtse recessen van 1665 de bepalingen met berekking tot de devolutic ingeval van een tweede of volgend huwelijk, naar de smaak van ons twintigste-eeuwers althans, minder helder geformuleerd zijn dan in de genoemde Roermondse Land-en Stadsrechten, lijkt het toch gerechtvaardigd, mede op basis van het betoog van Crahay dienaangaande, te oordelen, dat ze. ker in hoofdrekken de Maastrichtse regelingen in dezen analoog waren aan die wit het Roemondse Overkwartier. $\$ 2$

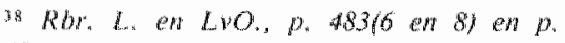
190.4916 en 8): zhe ook B.H.D. Hermesdorf.

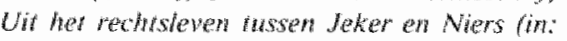
Limburgs Verleden, di.J. D. 273.

G.L.S.R. fol. 188,6.

\footnotetext{
to G.L.S.R., for. 188.7.

A. O.S.R., fol, 189,9.

42 L. Crahay, Conames.. Maestrich, $p$. $X X Y M$ th
} 
Een ander belangrijk facet uit het geheel van de oud "Limburgse" devolutieregels moge hier nog worden aangestipt. Het betreft de vraag of en inhoeverre het echtgenoten toegestaan was regelingen te treffen, waardoor de werking van de devolutie geheel of ten dele voorkomen kon worden. Laurillard, in zijn uit het midden van de vorige eeuw daterende Leidse dissertatie, was weliswaar van gevoelen, dat 'evenmin zoo staande als vóór het huwelijk' enige derogatie geoorloofd was, doch constateerde even verder in zijn betoog, dat 'desniettegenstaande de gewoonte algemeen in zwang was om aan het devolutie-regt te derogeren, zoowel bij huwelijksche voorwaarden als tijdens het huwelijk door overeenkomst of gemeenschappelijk testament'. ${ }^{3}$ In studies van Godding is aangetoond, dat zowel de doctrine als de jurisprudentie een zodanige derogatie toestonden, voorzover die tenminste uitging in coproductie van beide echtgenoten, hetzij derhalve bij huwelijkswoorwaarden hetzij bij wederkerig testament. ${ }^{44}$

Wat hebben de oud-'Limburgse' costumen ons in dezen te bieden?

De Maastrichtse 'Alde Caerte' en de artikelen van het Capittel der Recessen van 1665, dat handelt over het erfrecht bij versterf, bevatten ter plaatse waar het devolutiebeginsel tot uitdrukking is gebracht de woorden: 'behoudelijck het testament van de dooden'. ${ }^{45}$ Kennelijk was derogatie dus mogelijk. De mogelijkheid de wettelijke devolutieregelingen terzijde te stellen kende echter grenzen. Artikel 9 van het Capittel der Recessen, dat handelde over testamenten, bepaalde immers, dat het testament van de eerstgestorven echtgenoot aan de langstlevende, zonder diens instemming, niet het voordeel mocht ontnemen, dat de costumen hem gaven, te weten: de roerende goederen en het gebruik der onroerende goederen. ${ }^{46}$ De Maastrichtse costumen geven geen antwoord op de vraag of en inhoeverre echtgenoten al dan niet gezamenlijk inbreuk konden maken op de wettelijke rechten der kinderen. Wel weten wij, dat aldaar in notarieel opgemaakte testamenten in de 17 de en 18 de eeuw dergelijke inbreuken op de devolutieregeling regelmatig gemaakt werden. ${ }^{4} 7$

De Overkwartierse Land- en Stadrechten waren uitvoeriger dan de Maastrichtse Recessen inzake het al dan niet mogen afwijken van de devolutiebepalingen. Bij huwelijksvoorwaarden alsook bij testament, dat door beide echtgenoten gezamenlijk was opgemaakt, kon inbreuk gemaakt worden op de wettelijke rechten van de langstlevende." $\mathrm{Na}$ het overlijden van een der echtgenoten mocht de langstlevende evenwel geen testament maken of een andere regeling treffen met betrekking tot de goederen die op de kinderen gedevolveerd waren. ${ }^{49}$ Wel was het hem toegestaan een kind, dat zich jegens hem op enigerlei wijze kwalijk gedragen had, te onterven. Het als gevolg van zo'n onterving vrijkomende deel diende alsdan toe te vallen aan de overige kinderen "van den

\footnotetext{
"3.J.M. Laurihard, Het devolutiergegt, p. 19 en p. 85; zie ook P. Srockmans, Tractatus de jure deviurions, Cap. IX.

"4h. Godding, Dans quelle mésure pouwait an disposer de ses biens par fertament dans les anciens Pays-Bas méridionawx? in. Tijdschrift voor Rechtsgeschiedenis 50 (1982), p. $291 \mathrm{en}$ de aldau in mo. 59 genoemde liverainur; dezelf-

de, Le droit prive, nis, 648.

"Z Zie Recueit der Recessen, p. 201 en Cap. $X L H I$.

as Recuell der Recessen, Cap. XLII, 9

4) Vgl. A.Fl. Gehlen, Het notariaat in het Jweeherig Maastricht (Assen 1981), p. 198.

$\therefore$ G.L.S.R., fot 180,10.

A4 G.L.S.R., fol. 181, 11 .
} 
selven bedde'. ${ }^{30}$ Bij huwelijkswoorwaarden of gemeenschappelijk testament kon door de beide echtgenoten gezamenlijk wel inbreuk worden gemaakt op het wettelijk devolutievoordeel voor de kinderen, zo mag worden aangenomen, naar ik meen. De Land- en Stadrechten van 1619 verboden dit althans niet.

Ook dient hier nog gewag te worden gemaakt van de mogelijkheid een regeling van eenkindschap te creëren als gevolg waarvan de kinderen uit een eerder huwelijk van de langstlevende ouder erfrechtelijk op één lijn gesteld werden met kinderen, die uil een volgend huwelijk geboren zouden worden. Zowel te Maastricht als in het Roermondse Overkwartier behoefde een dergelijke regeling - zoals elders ook gebruikelijk - de instemming van het te dier zake competente plaatselijke gerecht, hetwelk dan voor een afweging van belangen stond. ${ }^{51}$ De uitwoerige regelingen in dezen in de Land- en Stadrechten uit het Overkwartier doen ons bij lezing concluderen, dat bij die belangenafweging eerst en vooral gelet werd op de belangen der voorkinderen. ${ }^{52}$

Tot zover deze beknopte schets van enige belangrijke facetten van devolutierecht zoals die in oud-'Limburgse' rechtsoptekeningen woorkomen. De storm van de Franse Revolutie, die - als bekend - een grondige omverwerping van wele vaak eeuwenoude zaken tot gevolg heeft gehad, is in alle hevigheid ook over het devolutie-instituut der oud-'Limburgse' territoria heengeraasd. Voor de Staatse, Oostenrijkse en Luikse gebieden, die met enige rijksheerlijkheden en de tweeherige stad Maastricht, na de verovering door Franse troepen, als departement van de Nedermaas, tezamen met acht andere geformeerde departementen in de Zuidelijke Nederlanden en het prinsbisdom Luik, op 1 oktober 1795 bij Frankrijk werden ingelijfd, werd bij besluit van 6 december 1796 door het Franse Directoire bepaald, dat elke nieuw uit te vaardigen wet ook aldaar onmiddellijk van kracht zou zijn, op gelijke wijze als elders in de Republiek. ${ }^{33}$ Nog geen twee maanden later verscheen de zogeheten 'Code Merlin', een overzicht van meer dan 400 wettelijke regelingen, die in de jaren 1789-1796 in Frankrijk waren uitgevaardigd. In het voorjaar van 1797 werd dit complex van revolutionaire wetten executoir verklaard in de negen bij de Franse Republiek geannexeerde departementen. ${ }^{54}$

Tot deze vóór de annexatie totstandgekomen regelingen behoorde ook een 'Décret relatif au partage des successions ab intestat' van 8-15 april 1791. Daarbij werden niet alleen oud-costumiere bepalingen, die leidden tot een ongelijke behandeling van kinderen of kindskinderen, die uit verschillende huwelijken van eenzelfde ouder of grootouder geboren waren, afgeschaft, maar

3u G.L.S.R., fol. 181,12.

* Recueil der Recessen, Cap. XL, 3; G.L.S.R., fol 190.4.

"G.L.S.R., fol. 190191.

"Vgl.J. Gillissen. Historische inleiding tot het recht, Antwerpen 198\%, p. 403 .

s" Als in vorige noot. Zie voor de invoering van de Franse revolutionaire wetgeving in de 'departements réunis" F. Stevens, De Franse wetgeving over het notarisambt en het Antwerpse notariat van 1794 tot 1814. Een instinutionele en kwantitatieve studie comuitgegeven diss. K.U. Lewien 1988), p. $15 \mathrm{v} / \mathrm{g}$. 
ook alle andere devolutiefacetten. ${ }^{\text {s5 }}$ Voor het departement van de Nedermaas zou onderzocht moeten worden of en inhoeverre de ook voor dit departement executoir verklaarde wet van 1791 al dan niet terstond na haar invoering in de rechtspraktijk geleid heeft tot een volledige terzijdestelling wan hei oud'Limburgse' devolutierecht. Boeiende kwesties van overgangsrecht, waarop door Imbert gewezen is, doch waaraan hier voorbijgegaan moet worden, dienen zich daarbij aan. ${ }^{56}$ Een dergelijk onderzoek zal daarenboven van groot belang kunnen zijn ter verkrijging van nader zicht op het devolutierecht in de oud-'Limburgse' territoria ten tijde van het Ancien Regime.

Dat het devolutiestelsel in het nieuwe Regime woor afschaffing in anmerking kwam, lag voor de hand. Tegen het einde van de 18 de eeuw kwam het instituut in Frankrijk immers nog slechts in enkele noordelijke en noordoostelijke territoria voor en bij het streven naar uniformering en codificatie van recht moest, zoals begrijpelijk is, wel voorbijgegaan worden aan costumiere rechtsverschijnselen, die ver van Parijs slechts hier en daar nog leefden in perifere gebieden. ${ }^{57}$ Bovendien - en dat was wellicht zeker zo klemmend - kleefclen er aan het devolutiesysteem elementen, die ernstig indruisten tegen beginselen, die met grote letters op de revolutionaire vaandlels dier dagen waren aangebracht. Dat kinderen van eenzelfde ouder, zij het ook dat zij stamden uit diverse echtelijke bedden van die ouder, erfrechtelijk ongelijk behandeld werden, strookte allerminst met de beginselen van 'égalité' en 'fraternité'. Rechten van primogenituur konden om gelijke reden niet geduld worden onder het nieuwe regiem. En dat er in het systeem van devolutie rekening werd gehouden met aard en herkomst van onroerend goed duidde op feodaliteit, op ongelijkheid en onvrijheid.

Met het wegvagen van dit alles kwam ook een einde aan de overlevings- en verzorgingsrechten voor de langstlevende echtgenoot, die in de costumiere devolutiebepalingen lagen ingebed. Door de Franse rechtshistoricus Paul Viollet is in de vorige eeuw erop gewezen hoezeer de afschaffing dezer wettelijke overlevings- en verzorgingsrechten veeleer een kwestie van onachtzaamheid der revolutionaire wetgevers is geweest dan van aanpassing aan gewijzigde maatschappelijke opvattingen. ${ }^{58}$ Het gevolg was, dat zowel in de Franse Code civil als in het Belgische Burgerlijk. Wetboek in de negentiger jaren van de vorige eeuw door middel wan een vruchtgebruik-constructie ten behoeve van de langsilevende echtgenoot aldaar opnieuw wettelijk vorm werd gegeven aan de verzorgingsgedachte. 59

Afgezien van de erfrecht-novelle van 1923, waarbij de langstlevende echtgenoot erfrechtelijk gelijkgesteld werd met een kind, heeft in ons land de ont-

"Zs Zie voor de tekst van dit 'dlecret' Pasinomie" on collection compleve des kois, decrets, arrêtes et réglements généraux aus peuvent ètre invoqués en belgique, prémière série "mise en ordre el annoree par J.B. Duvergier, T. II, Bruxelles 1834, p. 287-288. Ant. I, lid 3 , luidde: "Somt pareillemen abrogees les disposinions des coniumes aui, dans le partage des biens, lant menbles qu"immentbles, d'un mềne père ou d"une. mère, d'un whême aieul ou d'une même wï̌ule, citablissent des differences enire les enfons nés des divers martiages.

"5 J. Intherl, Le droin de dévolution, p. $228 \mathrm{~m} / \mathrm{g}$.

3 Zie J.H.A. Lakin en W.J. Zwalve, Hoofdstukken wir de Europese Codificariegenchiedenis (Groningen 19:86), p. $151 \mathrm{Wg}$.

sB P. Wollet, Histoire du droit cruil francais, $p$. $867-869$ en m.n. nt. 2 op p. 860 .

$59 \mathrm{Vgl} J$. Gilissen, Historische imleding, $p$. 642. 
wikkeling in dezen zich buiten de wet om voltrokken. Met wruchtgebruiklegaten, ouderlijke boedelverdelingen, fideicommissaire makingen en met andere vernuftige testamentaire constructies wordt in de praktijk nog steeds getracht tegemoet te komen aan de verlangens van zorgzame echtelieden, die zich bekommeren over de rechtspositie van de langstlevende hunner. In het kader van de totstandbrenging van het Nieuw Burgerlijk Wetboek is in dezen nu het woord aan onze wetgever. Reeds enkele decennia verdiept hij zich in een steeds maar groeiende stroom van hem aangereikte voorstellen ter regeling van de positie van de langstlevende en die der kinderen. ${ }^{60}$

Alvorens uit deze embarras du choix een 'definitieve' keuze te maken, zouden wij hem willen aanbevelen in zijn beschouwingen ook de historie van de materie die om regeling vraagt nogeens te bezien. Tot zijn verrassing, naar ik denk, zal hij dan ontdekken, dat het in 1981 bij de Tweede Kamer ingediende wetsvoorstel 17.141, alsmede een later daaraan toegevoegd concept-voorstel van het Ministerie van Justitie, op menig punt grote gelijkenis vertonen met hetgeen verankerd lag in het devolutiestelsel, zoals dat in een groot deel der Zuidelijke Nederlanden en elders oudtijds gegolden heeft. ${ }^{61} \mathrm{Hij}$ mene evenwel niet, dat het voorliggend wetsvoorstel de Limburgse rechtshistoricus wel uit het hart gegrepen moet zijn. Het tegendeel is het geval. De rechtsgeschiedenis heeft hem geleerd welke ernstige gebreken er kleefden aan het devolutiesysteem en tot welke juridische vragen en verwikkelingen zij geleid hebben. Dikwijls werschaft de rechtsgeschiedenis, zoals door Franz Wieacker is betoogd: "Information über das ehedem schon Gefundene, damit den Kommenden vermeidbare Irrwege oder Umwege erspart bleiben'. ${ }^{62}$

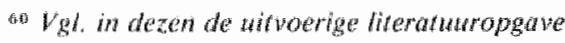
in New Burgerlith Werboek Naderlandse Wergeving, hosbladige editie), werzaneld en

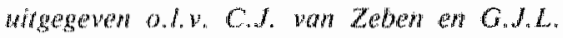

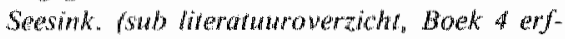

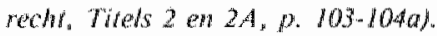

a finde 1988 is een atherwatief noorstel gelats.

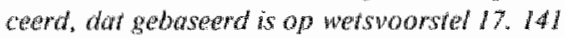
en op een conceproorstel van het Ministerie

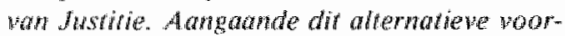

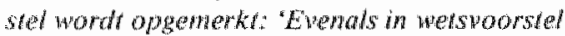

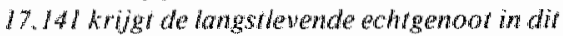
woorstel wow rechrswege hel wruchgebrik wan de malatenschap. Alan di wrachtgebrwk wor- den bevoegdheden verbanden, dhe ro leiden dat het whotrgebruk in feite neerkom op wot

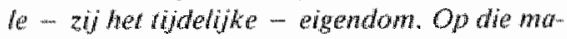
nier word bereikt dat goederen die bij het overlijden van de eersisterwende ectrgenoot en ook nog bij her owerlijen van de langstevende whinewoot annwezig zijn, bij het overlijen war de lamgsrianende nor de erfgenamen wan

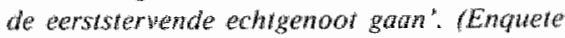
1989, ingested wonwege de Koninklitke Notamata Broedershapl.

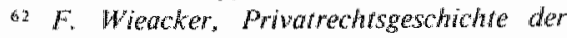

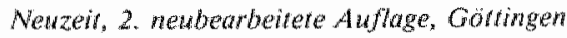
$1967: 0.619$. 
Voor mijn benoeming tot bijzonder hoogleraar in de rechtsgeschedenis van de Limburgse Territoria moge ik U, zeer gewaardeerde Heer Voorzitter, Mevrouw en Heren leden van het Bestuur van het Limburgs Gesched- en Oudheidkundig Genootschap, mijn oprechte dank betuigen. $1 \mathrm{k}$ ben mij ervan bewust dat deze uitverkiezing voor mij bijzondere verplichtingen met zich brengt jegens het Genootschap. I $\mathrm{k}$ hoop die naar Uw volle tevredenheid te kunnen inlossen. In elk geval zal ik mij daartoe vol ijver inzetten.

\section{Heren Leden van het College van Besimir dezer Unwersiteit,}

Zeer erkentelijk ben ik $U$ voor $U_{w}$ bereidwillige instemming met mijn benoeming tot bijzonder hoogleraar aan deze Uniwersiteit. Het stemt tot grote tevre.. denheid, met name onder rechtshistorici, dat juist bij deze nog jonge Universiteit het belang van de beoefening der rechtsgeschiedenis wordt onderkend. Met toewijding en zorgvuldigheid zal ik trachten de mij opgedragen taak te vervullen.

\section{Heren Leden van het College van Toezicht op deze leerstoel,}

Gaarne mag ik $U$ danken voor het door $U$ in mij gestelde vertrouwen dat geleid heeft tot de mij verheugende benoemingsvoordracht, die van $U$ is uitge-. gaan. Ik prijs mij gelukkig met de samenstelling van Uw College, waarvan mij gebleken is dat het deze leerstoel een bijzonder warm hart toedraagt. Uw vertrouwen in mij hoop ik niet te beschamen.

Dames en Heren hoogleraren, hoofddocenten, docenten en medewerkers van de Faculteit der Rechisgeleerdheid,

$U$ wil ik danken voor de hartelijke wijze, waarop U mij in $U_{w}$ midden hebt opgenomen. I $\mathrm{k}$ beschouw het als een groot voorrecht in deze Maastrichtse academische gemeenschap te mogen vertoeven. Ik kan $\mathrm{U}$ verzekeren, dat mijn eerste kennismaking met $U$ mij verlangend doet uitzien maar nader persoonlijk en collegiaal contact.

\section{Hooggeachte Spruit, Beste Jop,}

Ernstig betreur ik, dat in mijn rede onvoldoende aandacht is besteed aan de invloed van het gemene geleerde recht op met name de doctrine inzake devolutie. Het betoog zou al te uitvoerig geworden zijn. U zult mij deze omissie hier willen wergeven, omdat $U$ zeer wel weet, dat ik terdege besef hoezeer de bestudering van het Romeinse recht en zijn receptie van belang is bij de beoefening van de ond-vaderlandse rechtsgeschiedenis. Ik beschouw het als een groot voorrecht te mogen plaatsmemen naast een zo erudiet Romanist als Gij, waarde collega proximus.

Hooggeachte Moorman van Kappen, Beste Olav,

Grote dank ben ik $U$ verschuldigd. Het is mij een waar genoegen daarvan van- 
daag hier in publico gewag te mogen maken. Een meer toegewijd leermeesier dan Gij woor mij waart en nog steeds zijt, had ik mij niet kunnen wensen. Ruim vijftien jaar lang nu hebt Gij pre-en postpromotorale zorg aan mijn rechtshistorische vorming besteed en niets was U teveel om mij steeds weer te begeleiden op het pad van de rechtsgeschiedenis. Wie zich op dat pad begeeft, zal rijkelijk worden beloond, zo betoogde $U$ aan het slot van Uw oratie in 1973. De aan mij verstrekte leeropdracht aan deze Universiteit is onget wijfeld een van die beloningen. Doch er zijn vele beloningen meer, die ik dank zij Uw leiding reeds lang mocht genieten. Gij zijt en blijft mij een hoogst inspirerend voorbeeld, waarde leermeester en vriend.

\section{Hooggeachte Nève, Beste Paul,}

Van $U$ is het eerste initiatief uitgegaan, dat geleid heeft tot de inrichtig van de onderhavige leerstoel. Niet alleen de eerst benoemde ordinarius, maar ook de Limburgse gemeenschap dient $U$ voor dit initiatief hoogst erkentelijk te zijn. Naar beste vermogen zal ik vorm trachten te gewen aan hetgeen $U$ voor ogen heeft gestaan toen $U$ de inrichting van een bijzondere leerstoel in de rechtsgeschiedenis van de Limburgse Territoria aan deze Universiteit bepleitte. Van Uw genegenheid en steun weet ik mij verzekerd, gezien de hartelijke wijze waarop $\mathrm{U}$ mij vele jaren lang bent tegemoet getreden en gelet op $\mathrm{Uw}$ betrokkenheid met het Limburgse en Uw belangstelling voor en kennis van zaken van de Limburgse rechtshistorie.

Hooggewaardeerde hoogleraren, hoofddocenten, docenten en vorsers in de rech'sgeschiedenis uit Nederland' en België,

Graag maak ik van deze gelegenheid gebruik om $U$ hartelijk te danken voor de innernende wijze, waarop $U$ mij - een peregrinus - in Uw gelederen hebt ingelijfd. In de loop der jaren groeiden er, na de eerste kennismaking, nawwe contacten en zelfs vriendschap met velen Uwer. Jegens U allen, zeer gewaardeerde Nederlandse en Belgische beoefenaren van de rechtshistorie, voel ik mij ten zeerste verplicht voor het vele dat $U$ mij in woord, geschrift en vriendschap hebt geboden en steeds weer blijft bieden, warvan de aanwezigheid van velen Uwer hier vandaag weerom getuigt.

\section{Zeer gewardeerde Louis Berkvens,}

Graag grijp ik deze gelegenheid aan om mijn grote bewondering uit te spreken voor de wijze waarop $\mathrm{U}$ in de voorbije jaren als rechtshistorisch kwartiermaker in de Maastrichtse 'Nieuwenhof' hebt geopereerd. Het is voor een groot deel aan Uw inzet te danken, dat in een luttel aantal jaren binnen deze jonge faculteit een kampement kon worden ingericht, dat goede mogelijkheden biedt voor rechtshistorische exercities. Even amicaal en hartelijk als tot dusverre hoop ik nog lange tijd met $U$ te mogen samenwerken. Uw steun is mij onontbeerlijk zoals Gij hebt ervaren. 
Zeer wel besef $i k$, nu ik mij getrouw aan de traditie ten besluite meer in het bijzonder tot $U$ richt, dat er rondom mijn leerstoel waarschijnhijk nooit meer zoveel aandachtige toehoorders verzameld zullen zijn als op deze middag. Als $U$ dit verdrietig mag lijken voor iemand, die vol enthousiasme en in groot ornaat op die leerstoel heeft plaatsgenomen, dan vergist $U$ zich. Het zal mij juist een zeer grote vreugde zijn met enkelen Uwer, die zich in een studietijd, welke krap bemeten is, de weelde durven te veroorloven om zich vragend tot de rechtsgeschiedenis van de Limburgse Territoria te wenden, gezamenlijk op pad te gaan. Op mijn steun kunt $U$ rekenen.

Et hic huius orationis finis esto. 